NERS: Jurnal Keperawatan, Volume 13, No. 1, Maret 2017, (Hal. 42-49)

\title{
Lama Waktu Tidur Dengan Kejadian Obesitas Pada Remaja (Case Control Study)
}

\author{
Susmiati \\ Fakultas Keperawatan Universitas Andalas, Kampus Unand Limau Manis, Padang, 25163, \\ Indonesia \\ e-mail korespondensi: Email. susmiati.revalin@gmail.com
}

\begin{abstract}
The study on sleep duration has long been studied on various ethnic groups in developed countries, yet only a few have been conducted in developing countries. There is no information on the association between sleep duration and obesity on adolescents of Minangkabau ethnic. Based on the aforementioned reasons, there need a research on the association between sleep duration and obesity on adolescents. The aim of this study is to investigate the relationship between sleep duration and obesity on adolescents. The study was conducted by cross-sectional method. Samples comprise 178 junior high school students (91 obese and 87 non-obese) aged between 12-15 years in two regencies in West Sumatera. Independent variable was sleep duration, and obesity was dependent variable. Sleep duration was measured using self-reported sleep duration questionnaire and obesity was measured by anthropometric measurement. Statistical analysis was performed using SPSS. Data was analysed using student $t$-test, chi-square, and correlation analysis with $p<0.05$ being significant. There was no significant diference between sleep duration and obesity prevalence, $p=0.45$. The $t$-test on mean sleep duration suggested that there was no significant difference between sleep duration of normal and obese respondents $p=0.34$. There was an association between sleep duration and body fat percentage. Modification of sleep duration may be an alternative to reduce obesity prevalence.
\end{abstract}

Keywords: sleep duration, obesity (BMI), W/H ratio, body fat percentage.

\begin{abstract}
Abstrak
Studi tentang lama waktu tidur banyak dilakukan pada berbagai etnis di negara maju, tetapi sedikit sekali dilakukan negara berkembang. Belum ada informasi tentang hubungan lama waktu tidur dan obesitas pada remaja etnis Minangkabau. Berdasarkan alasan diatas perlu diteliti apakah terdapat hubungan antara lamanya waktu tidur dengan obesitas pada remaja. Tujuan penelitian adalah untuk mengkaji hubungan antara lama waktu tidur dengan obesitas pada remaja Penelitian dilakukan dengan desain cross sectional study. Sampel terdiri dari 178 orang siswi SMP ( 91 obesitas dan 87 normal) umur 12-15 tahun yang berada di 2 kab/kota di Sumatera Barat. Variabel bebas yang yang diukur adalah lama waktu tidur, sedangkan obesitas berperan sebagai variabel terikat. Lama waktu tidur diukur dengan self-reported sleep duration quesstionaire dan obesitas dengan pemeriksaan antropometri. Analisis statistik dilakukan dengan menggunakan dengan Student t-test, uji Chi-square dan uji korelasi $\mathrm{P}<0,05$ dianggap signifikan. Tidak ada perbedaan yang bermakna antara lama waktu tidur dengan kejadian obesitas $\mathrm{p}=0,45$. Dari uji perbedaan rata-rata waktu tidur didapatkan tidak ada perbedaan yang bermakna lama waktu tidur responden normal dan obesitas $p=0,34$. Terdapat hubungan antara lama waktu tidur dengan persen lemak tubuh $p=0,03$. Modifikasi lama waktu tidur dapat dijadikan sebagai alternative untuk menurunkan kejadian obesitas.
\end{abstract}

Kata kunci: lama waktu tidur, obesitas ( IMT), W/H rasio dan persen lemak tubuh

\section{PENDAHULUAN}

Berbagai metode pencegahan obesitas telah dilakukan melalui perubahan gaya hidup berupa pengaturan pola makan dan aktifitas fisik, namun angka obesitas terus meningkat. Pengobatan dan pencegahan obesitas ini belum dapat dicapai karena etiologi dan patogenesis obesitas sampai sekarang masih belum jelas dan masih diperdebatkan.

Obesitas pada remaja dapat menyebabakan komplikasi medis dan 
psikososial. Aspek medis meliputi gangguan metabolik seperti diabetes, hipertensi, dislipidemia, non alcoholic fatty liver, obstructive sleep apnoe dan gangguan ortopedik (Lee, 2009.). Komplikasi lain terutama pada wanita adalah polycystic ovarian syndrome (Seth \& Sharma, 2013). Komplikasi psikososial pada obesitas meliputi depresi dan ansietas. Remaja obesitas mempunyai kebiasaan makan dan kualitas hidup yang buruk (Değirmenci et al., 2015)

Prevalensi kelebihan berat badan dan obesitas juga meningkat pada anakanak dan remaja di negara berkembang, dari $8,1 \%$ sampai $12,9 \%$ di tahun 2013 untuk anak laki-laki dan dari $8,4 \%$ sampai $13,4 \%$ pada anak perempuan $(\mathrm{Ng}$ et al., 204). Prevalensi obesitas pada remaja umur 13-15 tahun di Sumatera Barat yang mayoritas etnis Minangkabau yaitu sebesar $10.8 \%$, terdiri dari $8,3 \%$ gemuk dan $2,5 \%$ sangat gemuk (obesitas) hampir sama dengan prevalensi nasional (Riskesdas, 2013). Sementara studi terdahulu melaporkan bahwa etnis Minangkabau memiliki pola diet yang berbeda dengan etnis lainnya di Indonesia dengan rata-rata asupan energi lebih rendah $(72,4 \%)$ dari Angka Kecukupan Gizi (AKG) Nasional (AKG 2150 kkal). Berdasarkan rasio PUFA:MUFA:SAFA, etnis Minangkabau memiliki kualitas pola diet lemak yang buruk dan asupan lemak yang lebih tinggi dibandingkan dengan kelompok etnis lainnya. ${ }^{6}$

Penelitian terdahulu lebih banyak menekankan pada asupan makan dan aktifitas fisik sebagai penyebab obesitas. Intervensi dengan mengatur asupan kalori dan meningkatkan aktifitas fisik masih belum efektif menurunkan kejadian obesitas. Faktor lain yang juga mempengaruhi kejadian obesitas adalah waktu tidur. Penelitian melaporkan bahwa pendeknya waktu tidur mengakibatkan perubahan fisiologi hormonal dimana terjadi penurunan leptin dan peningkatan ghrelin dan peningkatan rasa lapar dan nafsu makan yang memicu terjadinya obesitas (Taheri et al.,2004; Spiegel K et al., 2005; Fu JF et al., 2013). Disamping itu pendeknya waktu tidur juga menyebabkan penurunan toleransi glukosa dan sensitifitas insulin, peningkatan cortisol, peningkatan ghrelin dan penurunan leptin serta peningkatan rasa lapar dan nafsu makan (Zimberg et al., 2012).

Lama waktu tidur telah lama diteliti sebagai faktor resiko untuk kegemukan, tetapi mekanisme pasti masih belum jelas. Penelitian pada remaja menemukan bahwa remaja yang tidur kurang dari 8 jam perhari cenderung mengkonsumsi makanan tinggi kalori dari lemak dan rendah karbohidrat dibandingkan dengan remaja yang durasi tidurnya cukup $(8,5-$ 9,25 jam). Pendeknya waktu tidur dapat meningkatkan kejadian obesitas melalui perobahan pola makan yang berakibat perubahan keseimbangan energy (Weiss et al., 2010). Hasil yang berbeda didapatkan pada anak-anak Mexican American, dimana waktu tidur yang pendek berhubungan dengan obesitas melalui tingginya intake karbohidrat dan rendah lemak Martinez et al., 2017).

Beberapa studi melaporkan hubungan antara lama waktu tidur dan obesitas masih bervariasi dan dipengaruhi banyak faktor seperti usia, jenis kelamin dan aktifitas fisik (Shi et al., 2010; Hung et al., 2013; Suglia et al.,2014; Muqing et al., 2015; Ames et al., 2016). Penelitian lain mendapatkan peningkatan indek massa tubuh berhubungan dengan lama waktu tidur dan kualitas tidur (Peltzer \& Pengpid 2017).

Patofisiologi obesitas dan mekanisme mana yang paling berpengaruh masih belum jelas. Untuk itu perlu dikaji semua faktor yang mungkin berhubungan dengan obesitas ini, baik faktor genetik maupun faktor lingkungan. Pengobatan dan pencegahan obesitas yang efektif dapat dicapai jika diketahui patogenesis secara komprehensif. Sejauh ini banyak studi tentang interaksi genetik dan faktor lingkungan yang diteliti, tapi kajian yang mendalam mengenai lama waktu tidur terhadap obesitas masih terus berkembang. 
Studi tentang lama waktu tidur banyak dilakukan pada berbagai etnis di negara maju, tetapi sedikit sekali dilakukan negara berkembang. Belum ada informasi tentang hubungan lama waktu tidur dan obesitas pada remaja etnis Minangkabau. Berdasarkan uraian dalam latar belakang diatasdapat dirumuskan masalah penelitian sebagai berikut apakah terdapat hubungan antara lamanya waktu tidur dengan obesitas pada remaja.

\section{TUJUAN}

Untuk mengkaji hubungan lama waktu tidur dengan obesitas pada remaja remaja perempuan etnis Minangkabau.

\section{METODE}

Penelitian ini merupakan penelitian cross-sectional study di kota Padang dan Padang Panjang dari bulan April s/d Oktober 2015. Populasi adalah siswa perempuan sekolah menengah pertama (SMP) yang berada di 2 kota di Sumatera Barat, suku Minangkabau umur 12-15 tahun ( tinggal di Sumatera Barat, kedua orang tua serta kakek nenek berasal dari Sumatera Barat)

Subyek penelitian adalah dipilih secara proporsional stratified random sampling yaitu remaja perempuan yang memenuhi kriteria inklusi dan eklusi dimasukkan dalam subyek penelitian, sedangkan jumlah subyek berdasarkan proporsi obesitas di setiap sekolah. Subyek penelitian dibagi menjadi kelompok kasus dan kontrol. Jumlah kasus dan kontrol sama di setiap sekolah berdasarkan proporsi obesitas masing-masing sekolah. Kriteria eksklusi adalah subjek dengan gangguan imunologi dan infeksi dan konsumsi obat tidur. Kelompok kontrol diambil dari siswi sekolah yang sama yang mempunyai BMI Z score antara - 2 SD sampai +1 SD dan kelompok kasus BMI Z score diatas +2 SD standar WHO, dengan kriteria eklusi dan inklusi yang sama dengan kelompok kasus. Sampel terdiri dari 87 orang normal dan 91 orang obes.

Lama waktu tidur

Adalah waktu yang digunakan responden untuk tidur di malam hari. Data diambil berdasarkan self reported sleep duration questionnainaire. Lama waktu tidur ditentukan berdasarkan kebiasaan tidur dan bangun pada hari kerja dan libur. Rumus yang digunakan untuk menentukan lama waktu tidur $(2 / 7 \times$ weekends $+5 / 7 \times$ weekdays), kemudian dikelompokkan menjadi 3 kategori $<8,8-<10$, atau $\geq 10$ jam/hari berdasarkan kebutuhan tidur remaja.

Analisis data :

Analisis univariat digunakan untuk melihat distribusi data masing-masing variabel dan kemudian disajikan dalam bentuk tabel atau diagram. Data terdiri dari, ukuran antropometri (obes atau non obese), serta lama waktu tidur. Analisis bivariat digunakan untuk melihat hubungan antara lama waktu tidur dengan obesitas pada remaja. Uji $t$ test berpasangan dipakai untuk menganalisis beda rata-rata nilai antropometri antara obesitas dan normal. Uji chi-square digunakan untuk melihat hubungan antara lama waktu tidur dengan kejadian obesitas, sedangkan uji korelasi untuk menilai hubungan antara lama waktu tidur dengan nilai IMT, lingkar pinggang dan rasio lingkar pinggang dan panggul. Analisis statistik dilakukan dengan menggunakan SPSS (Versi 17) $\mathrm{p}<0,05$ dianggap signifikan. 


\section{HASIL DAN PEMBAHASAN}

Tabel 1. Karakteristik responden

\begin{tabular}{lrrc}
\hline \hline Variabel & Normal $(\mathrm{n}=87)$ & Obesitas $(\mathrm{n}=91)$ & $\mathrm{p}$ value \\
\hline \hline & & & \\
Umur & $13,60 \pm 0,85$ & $13,69 \pm 0,99$ & 0,49 \\
Tinggi badan & $151,92 \pm 6,22$ & $152,74 \pm 5,94$ & 0,37 \\
Berat badan & $48,21 \pm 8,03$ & $68,77 \pm 10,39$ & $0,01^{*}$ \\
BMI & $20,84 \pm 2,92$ & $29,43 \pm 3,43$ & $0,01^{*}$ \\
Lingkar pinggang & $69,74 \pm 7,28$ & $86,74 \pm 7,431$ & $0,01^{*}$ \\
Lingkar panggul & $87,14 \pm 9,52$ & $103,01 \pm 7,46$ & $0,01^{*}$ \\
W/H ratio & $0,81 \pm 0,19$ & $0,84 \pm 0,048$ & 0,17 \\
\% Lemak tubuh & $24,17 \pm 3,55$ & $31,18 \pm 1,97$ & $0,01^{*}$ \\
\hline \hline
\end{tabular}

Uji t test $* \mathrm{p}<0,05$

Tabel 2. Karakteristik tidur pada remaja berdasarkan indeks massa tubuh

\begin{tabular}{lccc}
\hline \hline Kategori Lama waktu tidur & Normal & obesitas & $\begin{array}{l}\text { p } \\
\text { value }\end{array}$ \\
\hline \hline Tidur pendek $(<8$ jam $)$ & $32(49,2 \%)$ & $33(50,8 \%)$ & 0.45 \\
Tidur normal ( 8-10 jam) & $46(46,5 \%)$ & $53(53,5 \%)$ & \\
Tidur Lama ( > 10 jam) & $9(64,3 \%)$ & $5(35,7 \%)$ & 0,34 \\
Lama waktu tidur & $8,28 \pm 1,24$ & $8,12 \pm 1,14$ & \\
\hline \hline
\end{tabular}

Penelitian dilakukan di Kota Padang dan Padang Panjang dengan responden siswi SMP umur 12-15 tahun.

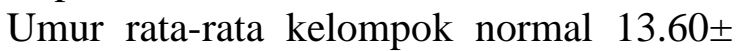
.855 dan obesitas $13.69 \pm .997$. Tidak ada perbedaan yang bermakna antara umur kelompok normal dan obesitas. Sedangkan berdasarkan berat badan, BMI, lingkar pinggang ,lingkar panggul dan persen lemak tubuh didapatkan perbedaan yang bermakna antara kelompok normal dan obesitas dengan $p<0,05$. ( Tabel 1)

Dari 65 orang responden dengan tidur pendek 33 orang ( 50,8\%) obesitas, sedangkankan dari 14 orang responden dengan tidur yang lama 9 orang $(64,3 \%)$ normal dan 5 orang $(35,7 \%)$ obesitas. Tidak ada perbedaan

yang bermakna antara lama waktu tidur dengan kejadian obesitas $\mathrm{p}>0,05$. Walaupun rata-rata waktu tidur pada normal lebih lama dibandingkan obes.

Tabel 2)

Dari uji perbedaan rata-rata lama waktu tidur kelompok normal lebih panjang dibandingkan kelompok obes. Secara statistik didapatkan tidak ada perbedaan yang bermakna lama waktu tidur responden normal dan obesitas $\mathrm{p}>$ 0,05. ( Tabel 2) 


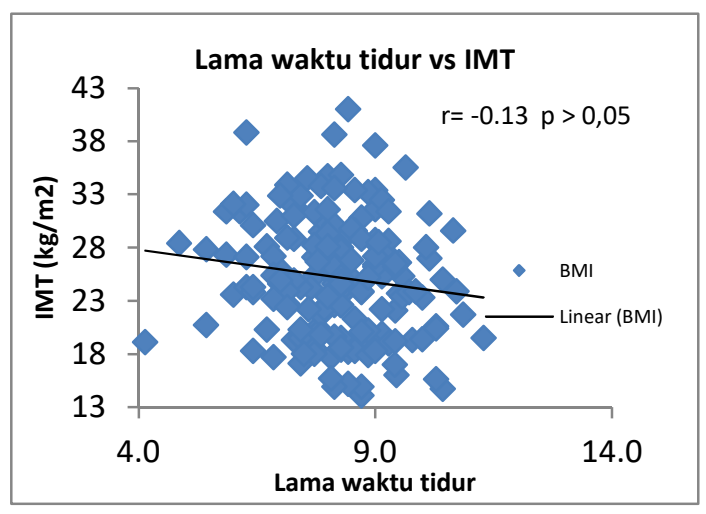

\section{Gambar 1. Hubungan lama waktu tidur dengan IMT}

Hubungan antara lama waktu tidur dengan IMT mempunyai kekuatan lemah dengan arah negatif, yang berarti semakin pendek waktu tidur semakin tinggi IMT, semakin lama waktu tidur semakin rendah IMT. Secara statistik tidak didapatkan hubungan yang signifikan antara lama waktu tidur dengan IMT $\mathrm{p}>0,05$. (Gambar 1)

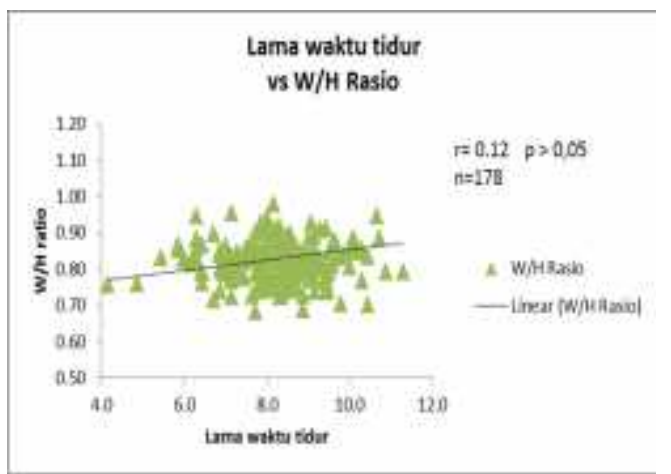

\section{Gambar 2. Hubungan lama waktu tidur dengan $\mathrm{W} / \mathrm{H}$ rasio}

Hubungan antara lama waktu tidur dengan rasio $\mathrm{W} / \mathrm{H}$ mempunyai kekuatan lemah dengan arah positif, yang berarti semakin pendek waktu tidur semakin rendah rasio $\mathrm{W} / \mathrm{H}$, semakin lama waktu tidur semakin tinggi rasio $\mathrm{W} / \mathrm{H}$. Secara statistik tidak didapatkan hubungan yang signifikan antara lama waktu tidur dengan rasio $\mathrm{W} / \mathrm{H}$ p > 0,05.(gambar 2)

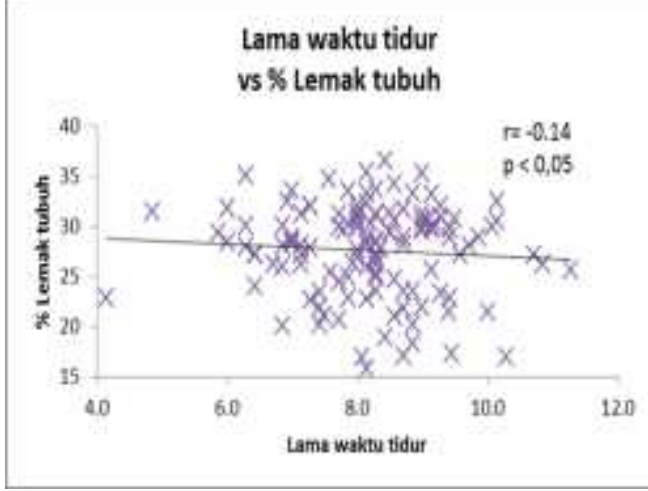

\section{Gambar 3. Hubungan lama waktu tidur denganpersentase lemak tubuh}

Hubungan antara lama waktu tidur dengan \% lemak tubuh mempunyai kekuatan lemah dengan arah negatif, yang berarti semakin pendek waktu tidur semakin tinggi \% lemak tubuh, semakin lama waktu tidur semakin rendah \% lemak tubuh. Secara statistik didapatkan hubungan yang signifikan antara lama waktu tidur dengan \% lemak tubuh $\mathrm{p}$ $<0,05$. (Gambar 3).

Hasil penelitian ini sejalan dengan penelitian Chaput et al, 2006 yang mendapat terdapat korelasi negatif antara lama tidur dengan IMT, walaupun ada perbedaan dimana pada penelitian Chaput et al didapatkan kekuatan sedang dan secara statistik ada hubungan yang bermakna $p<0,01$. Durasi tidur mungkin menjadi regulator penting berat badan dan metabolisme.

Penelitian Watanabe et al. 2010 menemukan bahwa waktu tidur yang pendek (5-6 jam) hanya berhubungan dengan obesitas pada laki-laki, tetapi tidak pada perempuan. Tidur yang tidak cukup dapat mengurangi produksi hormon leptin dan meningkatkan ghrelin yang menyebabkan seseorang merasa sangat lapar dan mencari pengurang rasa lapar dengan cemilan yang tinggi kalori. Beberapa penelitian menunjukkan adanya hubungan yang signifikan antara tidur yang kurang dengan obesitas pada remaja. Tidur yang kurang diduga akan menyebabkan gangguan regulasi hormonal 
terutama pengeluran hormon leptin (hormon kenyang) dan ghrelin (hormon yang menyebabkan kelaparan) yang berdampak pada pengaturan nafsu makan dan jumlah asupan makan (Seegers et al., 2011).

Penelitian yang dilakukan oleh Weiss et al (2010) terhadap 240 orang remaja menemukan bahwa remaja yang tidur kurang dari 8 jam per hari cenderung untuk mengkonsumsi kalori dari lemak dengan porporsi yang lebih besar, sedangkan konsumsi kalori dari karbohidrat lebih rendah. Penelitian lain yang dilakukan oleh Shi et al (2010) pada anak-anak Australia usia 5-15 tahun menemukan bahwa hubungan antara durasi tidur $(<9$ jam $)$ dan obesitas lebih kuat pada kelompok remaja awal. Studi intervensi dengan melakukan restriksi waktu tidur mendapatkan peningkatan konsumsi kalori dengan tanpa perubahan energy expenditure atau konsentrasi leptin dan ghrelin. Peningkatan asupan makan tanpa disertai peningkatan pengeluaran energy inilah yang berkontribusi terhadap kejadian obesitas (Calvin et al., 2013). Peningkatan waktu tidur pada remaja dapat menurunkan asupan makan, konsentrasi leptin puasa dan penurunan bera tbadan dibandingkan kelompok yang kurang waktu tidur (Hart et al., 2013).

Penelitian lain juga menunjukkan bahwa pendeknya waktu tidur dapat menyebabkan gangguan kebiasaan makan dari frekwnsi 3 kali sehari menjadi kurang atau lebih sering, tingkat asupan snack yang tinggi dan makanan tinggi kalori pada malam hari. Jadi walaupun dampak waktu tidur kecil, tapi kalau dilakukan terus menerus maka ini akan memyebabkan peningkatan kejadian obesitas (Dashti et al., 2015). Asupan energy berhubungan dengan lama waktu tidur $(\beta=-4.5 \mathrm{~kJ}, 95 \%$ CI -6.7 to $-2.4, \quad \mathrm{P}<0.001)$, tapi tidak terhadap kebiasaan waktu tidur. Telat tidur dan telat bangun berhubungan dengan kualitas diet yang jelek (Golley et al., 2013).
Sejumlah hormon memediasi interaksi antara durasi tidur yang pendek, metabolisme dan tingginya IMT. Dua hormon kunci yang mengatur nafsu makan yaitu leptin dan ghrelin. Kedua hormon ini memainkan peranan yang signifikan dalam interaksi antara durasi tidur yang pendek dan tingginya IMT. Leptin (an anorexigenic hormone) adalah adipocytederived yang menekan nafsu makan, sedangkan ghrelin (an orexigenic hormone) sebagian besar adalah peptide yang berasal dari abdomen yang menstimulasi nafsu makan (Broussard et al., 2016). Mediator lain yang memberi kontribusi terhadap metabolisme adalah adiponekatin dan insulin (Knutson et al., 2008). Selain meningkatkan ghrelin, penurunan leptin dan peningkatan rasa lapar dan nafsu makan, pendeknya waktu tidur juga mengakibatkan perubahan metabolik dan endokrin lain seperti penurunan toleransi glukosa dan sensitivity insulin, peningkatan konsentrasi cortisol dimalam hari. Pendeknya waktu tidur menyebabkan peningkatan asupan makan dan kelelahan, sehingga berakibat penurunan pengeluaran energy. Dampak ini semua akan mengakibatkan peningkatan obesitas (Zimberg et al., 2012). Disamping itu tidur yang pendek akan merangsang otak untuk meningkatkan asupan makan berkalori tinggi dan juga mempengaruhi aktifitas gen yang mangatur berat badan (Copinschi et al., 2014).

\section{SIMPULAN}

Tidak ada perbedaan yang bermakna ratarata waktu tidur antara normal dan obesitas $p>0,05$. Ada hubungan antara lama waktu tidur dengan persen lemak tubuh , makin pendek waktu tidur makin tinggi persen lemak tubuh.

\section{SARAN}

Perlu penelitian lebih lanjut tentang hubungan lama waktu tidur dengan asupan makan dan faktor resiko obesitas lain ( genetik, pola makan, aktifitas fisik dan mikrobiota usus) serta bagaimana interaksi 
lama waktu tidur terhadap faktor-faktor tersebut diatas

\section{UCAPAN TERIMA KASIH}

Terima kasih kepada seluruh partisipan dalam penelitian ini. Penelitian ini didanai oleh DIPA Fakultas Keperawatan tahun 2016.

\section{DAFTAR PUSTAKA}

Ames ME, Holfeld B, Leadbeater BJ. Sex and age group differences in the associations between sleep duration and BMI from adolescence to young adulthood. Psychol Health. 2016 Aug;31(8):976-92. doi: 10.1080/08870446.2016.1163360. Epub 2016 Mar 25.

BroussardJL, Kilkus M, Delebecque F, Abraham V, Day A, Whitmore HR. Elevated ghrelin predicts food intake during experimental sleep restriction. Obesity (Silver Spring). 2016 Jan;24(1):132-8. doi: 10.1002/oby.21321. Epub 2015 Oct 15.

Calvin AD, Carter RE, Adachi T, Macedo PG, Albuquerque FN, van der Walt C. Effects of experimental sleep restriction on caloric intake and activity energy expenditure. Chest. 2013 Jul;144(1):79-86. doi: 10.1378/chest.12-2829.

Chaput JP, Lambert M, Donald KG, et al., Short Sleep Duration Is Independently Associated With Overweight and Obesity in Quebec Children. Can J Public Health 2011;102(5):369-74

Copinschi G, Leproult R, Spiegel K.The important role of sleep in metabolism. Front Horm Res. 2014;42:59-72. doi: 10.1159/000358858. Epub 2014 Apr 7.

Dashti HS, Scheer FA, Jacques PF, Lamon-Fava S, Ordovás JM. Short sleep duration and dietary intake: epidemiologic evidence, mechanisms, and health implications. Adv
Nutr. 2015 Nov 13;6(6):648-59. doi: 10.3945/an.115.008623. Print 2015 Nov.

Değirmenci T, Kalkan-Oğuzhanoğlu N; Sözeri-Varma G, Özdel O, Fenkçi S. 2015. Psychological Symptoms in Obesity and Related Factors. Noro Psikiyatr Ars. ;52(1):42-46. doi: 10.5152/npa.2015.6904. Epub 2015 Mar 1.

Hatma RD, 2001. Nutient Intake Patterns and Their Relations To lipid Profiles In Diverse Ethnic Populations. Jakarta. P 54, 68, 69, 77.

Hart CN, Carskadon MA, Considine RV, Fava JL, Lawton J, Raynor HA. Changes in children's sleep duration on food intake, weight, and leptin. Pediatrics. 2013 Dec;132(6):e1473-80. doi: 10.1542/peds.2013-1274. Epub 2013 Nov 4.

Fu JF et al., 2013, Short Sleep Duration as a Risk Factor for Obesity in Childhood Is Associated with Increased Leptin, Ghrelin, and Orexin Levels HK J Paediatr (new series) 2013;18:152-158

Golley RK, Maher CA, Matricciani L, Olds TS. Sleep duration or bedtime? Exploring the association between sleep timing behaviour, diet and BMI in children and adolescents. Int J Obes (Lond). 2013 Apr;37(4):546-51. doi: 10.1038/ijo.2012.212. Epub 2013 Jan 8.

Hung HC et al., 2013. The association between self-reported sleep quality and overweight in a Chinese population.Obesity (Silver Spring). 2013 Mar;21(3):486-92.

Knutson KL, Van Cauter E. Associations between sleep loss and increased risk of obesity and diabetes. Ann N Y Acad Sci. 2008;1129:287-304. doi: 10.1196/annals.1417.033.

Lee YS. 2009. Consequences of childhood obesity. Ann Acad Med Singapore. ;38(1):75-7.

$\mathrm{Ng} \mathrm{M}$, Fleming $\mathrm{T}$, Robinson $\mathrm{M}$, et al., 2014. Global, regional, and national prevalence of overweight and obesity 
in children and adults during 19802013: a systematic analysis for the Global Burden of Disease Study 2013. Lancet, 384(9945), 766-781.

Muqing C, Yanna Z,Baoting H,Wenhan ,Y ajun C. 2015. Association between sleep duration and obesity is age- and gender-dependent in Chinese urban children aged 6-18 years: a crosssectional study. BMC Public Health15:1029

Martinez SM, Tschann JM, Butte NF, Gregorich SE, Penilla C, Flores E, . Short Sleep Duration Is Associated With Eating More Carbohydrates and Less Dietary Fat in Mexican American Children. Sleep. 2017 Feb 1;40(2). doi: 10.1093/sleep/zsw057

Peltzer K and Pengpid S. Sleep Duration, Sleep Quality, Body Mass Index, and Waist Circumference among Young Adults from 24 Low- and MiddleIncome and Two High-Income Countries. Int $\mathrm{J}$ Environ Res Public Health. 2017 May 26;14(6). pii: E566. doi:10.3390/ijerph14060566.

Riset Kesehatan Dasar (Riskesdas), Laporan Nasional 2012, Desember 2013

Seegers V, Petit D, Falissard B, Vitaro F, Tremblay RE, Montplaisir J. Short Sleep Duration and Body Mass Index: A Prospective Longitudinal Study in Preadolescence. American Journal of Epidemiology, Volume 173, Issue 6, 15 March 2011, Pages 621-629, https://doi.org/10.1093/aje/kwq389 Seth A dan Sharma R. 2013. Childhood obesity. Indian J Pediatr. 80(4):30917. doi: 10.1007/s12098-012-0931

Spiegel K et al., 2005. Sleep loss: a novel risk factor for insulin resistance and Type 2 diabetes.J Appl Physiol. 2005 Nov;99(5):2008-19.

Shi et al (2010). Short sleep duration and obesity among australian Children. BMC Public Health 10:609

Suglia SF, Kara S, Robinson WR.2014.Sleep duration and obesity among adolescents transitioning to adulthood: do results differ by sex? J Pediatr. 2014 Oct;165(4):750-4

Weiss A, Xu F, Storfer-Isser A, Thomas A, Ievers-Landis CE, Redline S.The association of sleep duration with adolescents' fat and carbohydrate consumption.

Sleep. 2010 Sep;33(9):1201-9.

Watanabe M, Kikuchi H, Tanaka K, Takahashi M. Association of short sleep duration with weight gain and obesity at 1-year follow-up: a largescale prospective study. Sleep. 2010 Feb;33(2):161-7.

Zimberg IZ, Dâmaso A, Del Re M, Carneiro AM, de Sá Souza H, de Lira FS. Short sleep duration and obesity: mechanisms and future perspectives. Cell Biochem Funct. 2012 Aug;30(6):524-9. doi: 10.1002/cbf.2832. Epub 2012 Apr 4 